\title{
TEMPORAL ARTERIOGRAPHY \\ A NEW TECHNIQUE FOR THE INVESTIGATION OF GIANT CELL ARTERITIS AND POLYMYALGIA RHEUMATICA
}

BY

\author{
LEWIS A. GILLANDERS, R. W. STRACHAN, AND D. W. BLAIR \\ Aberdeen Royal Infirmary
}

The work which has led to this report was undertaken in an attempt to improve the diagnostic accuracy and thereby the treatment of giant cell arteritis and polymyalgia rheumatica. Whether these conditions are the same, related, or quite different diseases is a well-known problem; detailed studies have provided support for all three possibilities (Gordon, Rennie, and Branwood, 1964; Hamrin, Jonsson, and Landberg, 1964; Andrews, Dixon, Beardwell, Kay, Wanka, and Wong, 1966; Bruk, 1967).

Confirmation of the clinical diagnosis of giant cell arteritis generally rests on the evidence obtained from a blind biopsy of the superficial temporal artery. Some recent reports have shown that the arteritis may be revealed by this investigation even in the absence of any clinical abnormality of the vessel (Hamrin and others, 1964; Olhagen, 1963; Alestig and Barr, 1963; Dixon and others, 1966; Bruk 1967). Nevertheless, it must be remembered that the disease process is patchy in nature and this procedure may therefore fail to confirm the diagnosis when an uninvolved segment of the vessel happens to be excised.

We now wish to draw attention to the technique of selective superficial temporal arteriography to emphasize its particular suitability to the clinical field under discussion. Our study has confirmed that this procedure can demonstrate the presence of giant cell arteritis when blind arterial biopsy in the temporal region has been negative or inconclusive.

\section{Method}

The examination is done under local anaesthesia. A horizontal incision about $1.5 \mathrm{~cm}$. in length is made just above the malar bone in front of the ear. The superficial temporal artery is exposed, tied off proximally, and cannulated distally, using a tapered length of polyethylene catheter PE 160 (Fig. 1). The cannula is not introduced by more than $1 \mathrm{~cm}$. since the artery frequently branches just above the malar bone and impaction of the catheter could occur leading either to difficulty with the injection or to failure of visualization of all the branches.

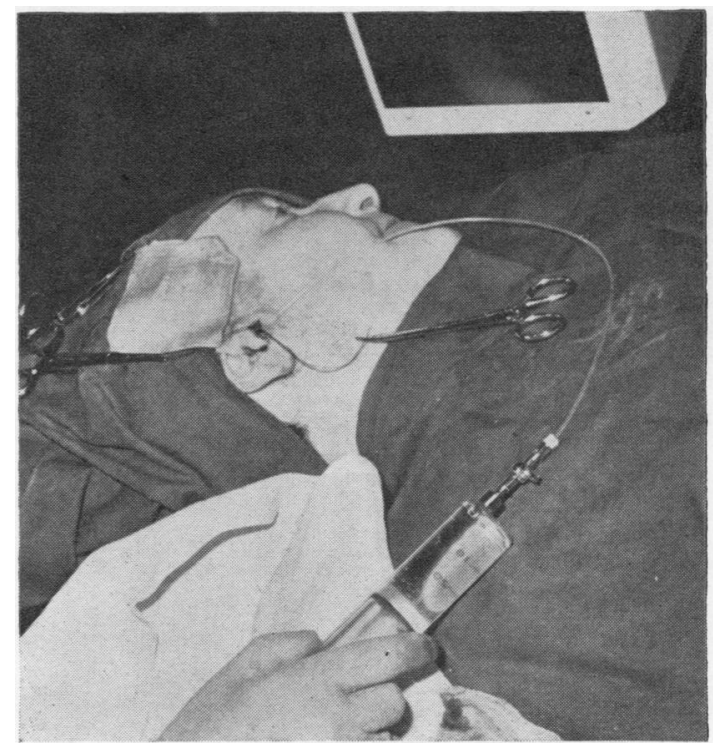

Fig. 1.-Polyethylene catheter inserted into the superficial temporal artery.

The head is then turned into the supine position, 2.5 $\mathrm{ml}$. of $\mathbf{4 5}$ per cent. Hypaque is injected slowly by hand, and a single lateral radiograph is taken at the termination of the injection.

The patient usually complains of a burning sensation in the head for a few seconds but this is not of such severity as to cause movement. After it has been confirmed that the vessel has been satisfactorily visualized, the catheter is removed and a small portion of the temporal artery is excised for histological examination. 


\section{Results}

The typical radiological appearances of giant cell arteritis are shown in Fig. 2 and contrast strikingly with the smooth outline of normal vessels demonstrated in Fig. 3. That these appearances are not due to atheroma has been established by a review of carotid angiograms in a series of patients with atheromatous occlusion of the internal carotid artery. No evidence of such arterial abnormality

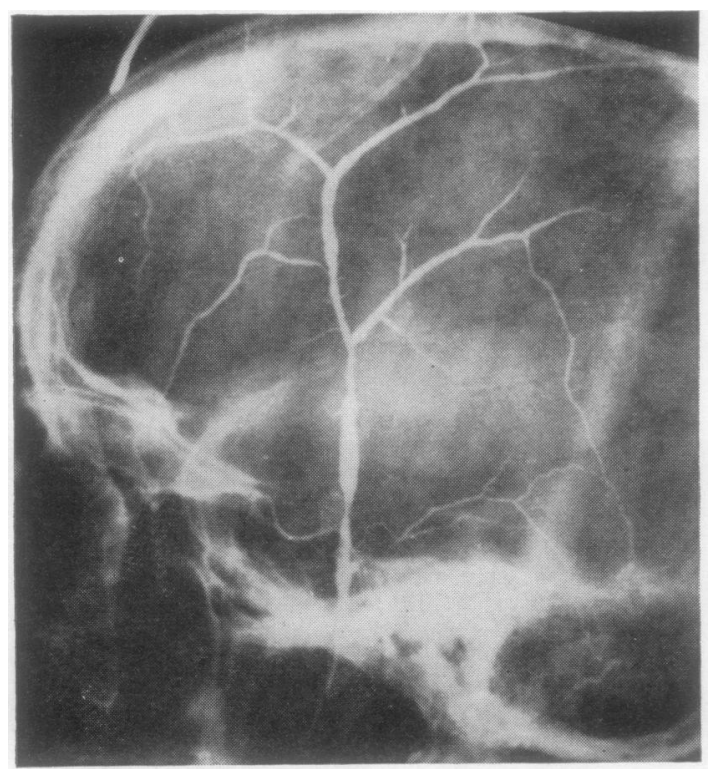

Fig. 2.-Temporal arteriogram showing numerous long, dilated and stenotic segments affecting most of the branches of the superficial temporal artery.

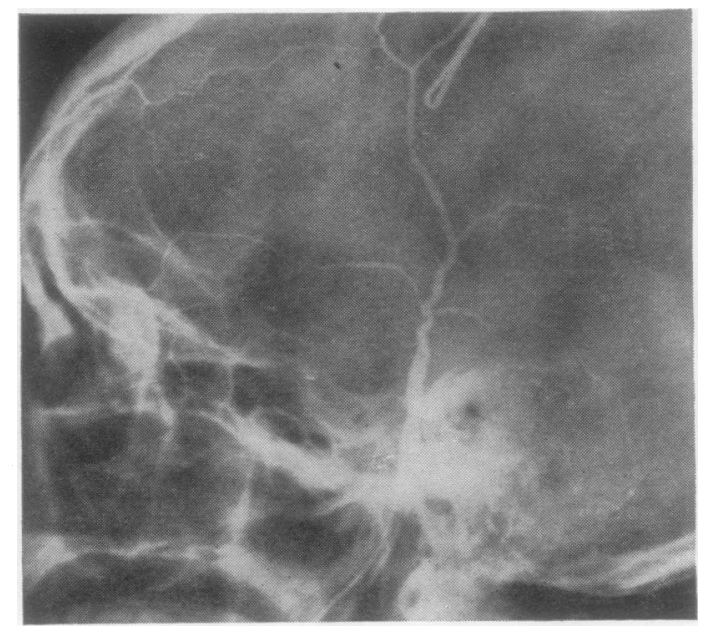

Fig. 3.-Temporal arteriogram showing normal appearances of the branches of the superficial temporal artery. was observed in the branches of the superficial artery in these cases. A further group of patients suffering from polyarteritis nodosa, Takayasu's arteritis, rheumatoid arthritis, and scleroderma was also investigated by this technique, since there was the possibility that arteriography might have been of diagnostic value; in no case were abnormalities of the type described above demonstrated.

A preliminary study by temporal arteriography has now been undertaken in fifteen patients who were considered clinically to be suffering from either giant cell arteritis or polymyalgia rheumatica. The latter diagnosis was made before the angiographic procedure on the basis of the clinical criteria discussed by Gordon and others (1964). When the study is completed a detailed interpretation of the findings regarding the relationship between giant cell arteritis and polymyalgia rheumatica is to be published by the physicians who referred their patients for arteriographic assessment.

\section{Discussion}

To our knowledge studies by selective temporal arteriography have not been reported previously. Palm (1958) described 31 cases of temporal arteritis in which carotid angiograms had been carried out in four, and referred to one case where the temporal and occipital arteries showed narrowed and dilated segments. Hinck, Carter, and Rippey (1964) referred to a German report in which similar appearances were said to be present in some of the branches of the anterior and middle cerebral arteries; in this case the branches of the external carotide artery were normal.

The results of our study so far indicate that temporal arteriography and biopsy are complementary investigations and can be combined as a single diagnostic procedure. Arteriography, by allowing visualization of the full extent of the superficial temporal artery and its branches, can direct the attention of the surgeon to a particularly diseased segment and thus permit a selective biopsy. In particular it appears that, in any research study concerning giant cell arteritis and polymyalgia rheumatica, temporal arteriography with selective or blind biopsy, as appropriate, is the best form of investigation.

Recently Wadman and Werner (1967) again emphasized the danger of treating the syndromes referred to in this paper with analgesic drugs. It is our belief that the improved diagnostic accuracy which is provided by temporal arteriography will encourage the proper early use of steroid therapy and avert the tragic complications of giant cell arteritis such as blindness. 


\section{Summary}

Selective temporal arteriography as a complementary procedure to arterial biopsy has been performed in fifteen patients suffering from giant cell arteritis or polymyalgia rheumatica. The characteristic radiological appearances of giant cell arteritis are illustrated and attention is drawn to the fact that the angiographic technique can permit a diagnosis even when blind biopsy of the vessel is negative. It is suggested, therefore, that angiography should be used routinely in association with biopsy of the superficial temporal artery.
No radiological abnormality was demonstrated in a number of patients with polyarteritis nodosa, Takayasu's arteritis, rheumatoid arthritis, and scleroderma, who were also examined by this method.

The authors wish to thank Dr Ian Gordon, Dr C. D. Needham, and Dr L. S. Bain for their interest in this work and for inviting us to examine their patients. Figures 2 and 3 are reproduced by kind permission of the Editors of Clinical Radiology.

\section{REFERENCES}

Alestig, K., and Barr, J. (1963). Lancet, 1, 1228 (Giant-cell arteritis).

Andrews, F. M. (1965). Ann. rheum. Dis., 24, 432 (Polymyalgia rheumatica).

Bruk, M. I. (1967). Ibid., 26, 103 (Polymyalgia rheumatica).

Dixon, A. St. J., Beardwell, C., Kay, A., Wanka, J., and Wong, Y. T. (1966). Ibid., 25, 203 (Polymyalgia rheumatica and temporal arteritis).

Gordon, I., Rennie, A. M., and Branwood, A. W. (1964). Ibid., 23, 447 (Polymyalgia rheumatica).

Hamrin, B , Jonsson, N , and Landberg, T. (1964). Lancet, 1, 397 (Arteritis in polymyalgia rheumatica).

Hinck, V. C., Carter, C. C., and Rippey, U. G. (1964). Amer. J. Roentgenol., 92, 769 [Giant cell (cranial) arteritis: a case with angiographic abnormalities].

Olhagen, B. (1963). Acta rheum. scand., 9, 157 (Polymyalgia rheumatica. A form of senile arteritis).

Palm, E. (1958). Acta ophthal. (Kbh.), 36, 208 [The ocular crisis of the temporal arteritis syndrome (Horton)].

Wadman, B., and Werner, I. (1967). Lancet, 1, 597 (Therapeutic hazards of phenylbutazone and oxyphenbutazone in polymyalgia rheumatica).

\section{L'artériographie temporale}

Une nouvelle technique pour l'étude de l'artérite à cellules géantes et de la polymyalgia rheumatica

\section{RÉSUMÉ}

Une artériographie temporale sélective comme procédure complémentaire à la biopsie artérielle a été faite à 15 malades atteints d'artérite à cellules géantes ou de polymyalgia rheumatica. Les aspects radiologiques caractéristiques de l'artérite à cellules géantes sont illustrés et l'attention est attirée sur le fait que la technique angiographique peut permettre un diagnostic même quand la biopsie indirecte de l'artère est négative. Il est suggéré que cette angiographie devrait être un procédé régulier en association à la biopsie de l'artère temporale superficielle.

Aucune anomalie radiologique n'avait été démontrée chez un certain nombre de malades atteints de polyartérite, noueuse d'artérite de Takayasu, de polyarthrite rhumatoïde, et de sclérodermie, qui avaient été aussi examinés par cette méthode.

\section{Arteriografía temporal}

Una nueva técnica para la Investigación de la arteritis de célula gigante y la polimialgia reumática

\section{SUMARIO}

La arteriografía temporal selectiva como procedimiento complementario de la biopsia arterial se ha practicado en quince pacientes que padecen de arteritis de célula gigante o polimialgia reumática. Se ilustran los aspectos radiológicos característicos de la arteritis de célula gigante y se llama la atención hacia el hecho de que la técnica angiográfica puede permitir el diagnóstico aun cuando la biopsia ciega del vaso sea negativa. Así pues, se sugiere que la angiografía debiera usarse rutinariamente en conjunción con la biopsia de la arteria temporal superficial.

No se reveló ninguna anormalidad radiológica en un número de pacientes con poliarteritis nodosa, arteritis de Takayasu, poliartritis reumatoide y escleroderma, quienes fueron también examinados por este método. 